\title{
Financial Architecture in the Different Life Cycle Stages
}

Anastasia N. Stepanova,

Associate Professor, Research Fellow

Corporate Finance Center, School of Finance,

National Research University Higher School of Economics

26, Shabolovka st., Moscow, Russia

E-mail: anastasianstepanova@gmail.com

Izabella G. Kazaryan,

MA in Finance

National Research University Higher School of Economics

26, Shabolovka st., Moscow, Russia

E-mail: isabellaghazaryan@gmail.com

\begin{abstract}
In this article, we consider the relation between capital structure, corporate governance, ownership structure and performance of a company depending on its life cycle stages. The central aim of this study is to define the most sustainable and effective types of financial architecture by using the cluster and regression analysis. This study describes the three stages of the life cycle of a company: the first stage is growth, followed by maturity and finally the stage of decline, but for our research we only examine companies in the maturity stage. The research includes 11 countries from emerging markets and the primary sample includes 4,675 non-financial companies from 2011 to 2015. As the measure of a company's performance, we used Tobin's Q coefficient and total shareholder return. The primary sample was divided into the 3 life cycle stages by using the approach of comparing the growth rates of revenues at the average rate of revenue growth in the industry; however, we did not consider the earlier stages of the life cycle due to the specificity of the sample. A cluster analysis was performed on the sample for the growth and maturity stages in order to show the difference between the clusters that depends on the life cycle stages. We analyzed the clusters' sustainability by regression analysis in each cluster. We described the influence of the financial architecture component on market performance. The results indicate more than one sustainable cluster and demonstrate the influence of the ownership structure, capital structure and the board characteristics on the company's efficiency depending on the stage of the life cycle, which proves there is a need to take into account the issues of the life cycle. The managers and directors of a company can use results of this study when developing a company's strategy, especially during the transition period from one life cycle to another.
\end{abstract}

Keywords: capital structure; ownership structure; emerging markets; cluster analysis; life cycle stages; performance JEL: G3 


\section{Introduction}

The main goal of companies has always been to maximize company performance. Recently, the need to improve firm performance has increased because of competitive growth in the developed and emerging markets. A company is a dynamic system that goes through different stages of the life cycle over time, while at the same time, it is also undergoing significant changes due to different natural processes within the company and in the market. The company's financial architecture also changes over the life cycle adjusting to fit the goals and needs of the company. In this paper, we try to answer the question of what the traditional patterns of corporate architecture are during the different stages of the life cycle. This question looks even more challenging for the emerging markets that have a significantly higher concentration of ownership, creating a serious impact on the firm's architecture as a whole.

Let us take a look at the example of the Russian Aquaculture (RA) Company. In the birth stage, the company's ownership was concentrated in the hands of the Corsico Company (around 95\%). The ownership concentration had a positive effect on governance and the company's performance, contributing to stakeholders' motivation. During the first 10 years, the company introduced several product lines, extended its geographical presence in terms of distribution, and enlarged the number of procurement contracts. In 2010, the company launched an IPO of its shares, which usually coincides with moving into the next stage of a company's life cycle. In 2011, the RS Group and the Volga Group established the joint company, RSEA Holdings Limited, which owns $60.94 \%$ of RA ${ }^{1}$. The company continued to grow and the ownership was still concentrated during this stage of the life cycle. In the early stages of this life cycle, the interests of the major and minority owners are the same and this high level of concentration has a positive influence on the corporate governance decisions and financial results of a company. Approximately in 2014, the company demonstrated steps moving toward the maturity stage of the life cycle, while still supporting the ownership concentration at quite a high level (around 95\% in the hands of three of the largest shareholders). This is an interesting case because it challenges the idea about dispersed ownership in the late stages of corporate life cycles.

Currently, many studies are devoted to what influences firm performance. The main studies relate to building stylized models for efficiency analysis, which explains the influence of separate mechanisms on a company's performance. A large number of important interrelated characteristics have an impact on a company's performance. The conventional approach to the study of the relationship between characteristics and corporate performance applies models accounting for one or several indicators of ownership and governance. At the same time, it is currently extremely difficult to optimize the specific separate indi- cator for firm ownership. This, naturally, forces us to apply an integrated approach to the study of firm architecture. Myers (1999) defines a company's financial architecture as the set of its financial performance, such as the legal form of business organization, capital structure, ownership structure and the performance of the board of directors. These characteristics have a significant impact on the investment risks, creating unique risks for a company and its sensibility to systematic risk. The last two characteristics, ownership structure and corporate governance, define the methods of coordinating the relationship between owners, and the regulation of conflicts of interest between the owners and managers. The concept of a firm's financial architecture involves the necessity of taking into account the interdependencies between its components.

Studies devoted to the influence of ownership structure on firm performance focus mainly on three aspects: the concentration of ownership, the role of insider ownership and the state ownership. The ownership structure determines the characteristics of agency relations in the company. In this paper, we consider the agency theory in describing three types of agency conflicts in ownership structure: a conflict between state and private owners, a conflict between owners and managers [Jensen, Meckling, 1976], and one between majority and minority owners [Shleifer, Vishny, 1997; Gilson, Gordon, 2003]. A large set of studies is devoted to researching financial leverage problems, followed by those of overinvestment and underinvestment [Myers, 1977; Stulz, 1990; McConnell, Servaes, 1995]. The first three mechanisms can also be interrelated with a stage of the life cycle. The concept of life cycle stages suggests that the characteristics evolve while the firm is going through the different stages. There are several types of theories regarding a company's life cycle stages. Currently, the most well known life cycle models are Adizes' model [Adizes, 1988] and Greiner's model [Greiner, 1998]. Both life cycle models have common assumptions. First, that the reasons for any changes in the organization are internal. Second, all companies are faced with similar problems when going through the stages of the life cycle and when solving them, they experience certain changes. Therefore, in order to achieve sustainable growth in a particular stage of the life cycle, the elements of the company's financial architecture need to adapt to the changes in the life cycle stages.

In this paper, we determine the types of financial architecture at different stages of the life cycle and denote the most sustainable types depending on the life cycle stage. We try to answer the following questions of whether there are sustainable types of financial architecture at different life cycle stages and if we can use these results in the emerging market for the optimization of firm performance.

The paper has been organized so that the second section defines the notion of financial architecture and presents a literature review devoted to the interrelations of all 
the components of financial architecture with market performance during different life cycle stages. The hypotheses were formulated by analyzing the prerequisites and conclusions of classical and recent studies. The third section describes the definitions of a company's life cycle stage and other methods. The fourth section describes the major empirical results with the conclusion coming in section five.

\section{Related literature and hypotheses}

\section{What is financial architecture and its characteristics?}

The concept of financial architecture as the basis for an integrated approach for evaluating a company's performance was first proposed in 1999 by Myers [Myers, 1999]. Financial architecture considers several of the corporate finance characteristics of capital structure, such as financial leverage, ownership structure and corporate governance mechanisms, as an integrated system. These components established some major mechanisms and strategic decision-making procedures, so it can be claimed that financial architecture is able to influence performance. The main characteristic of a company's performance in corporate finance theory is usually that of the allocation of capital structure because it reflects the ratio of debt and equity, which is often used in the financing of the company's long-term development. Recently, much attention has been devoted to the structural characteristics of the board of directors in studies published in the top financial journals. As mentioned earlier, the existing literature focuses on the study of the influence of only one component on a company's performance. This paper differs from previous research in that different components of the financial architecture are taken into consideration. This section of the paper provides an overview of the literature that is devoted to the interrelation of different characteristics of financial architecture with performance. In order to formulate the hypotheses about the influence of financial architecture and its components on the strategic efficiency of a company, all studies have been divided into three blocks, which are devoted to analyzing the impact on their three main components.

\section{Capital structure and a company's life cycle}

From one of the most important works [Modigliani, Miller, 1958] dealing with capital structure explanation, three main theories have been defined: the trade-off theory, the pecking order theory and the market-timing hypothesis. A company financial manager should analyze the dignity and the lack of different fund sources before choosing the best one, keeping in mind which one can provide the optimal capital mix or which one can decrease the capital cost.

Financial leverage is the ratio of debt to equity and the first question that arises in studies of leverage is the problem of over-investment and under-investment. Many studies are devoted to the optimization of capital structure, which is based on three theories: the trade-off theory [Frank, Goyal, 2008; Shyam-Sunder, Myers, 1999; Canarella, Nourayi, Sullivan, 2014; Chung-Te Chang, 2014], empirical testing of the pecking order hypothesis [Myers, 1984; Baltaci, Ayaydin, 2014] and the signaling and agency models [Baker, Wurgler, 2002; Fernandes, 2011]. The most relevant explanation for leverage is the trade-off theory in which a capital structure is selected so that the tax and incentive advantages of debt exactly compensate bankruptcy costs at the margin. The tradeoff theory also considers that the capital structure of a firm should be adapted to the indicators of that firm's assets. For instance, a profitable company in the maturity stage with stabilized cash flows should have high leverage, because it is better for use with debt tax shields and has a lower probability of financial distress and the costs of financial distress may be higher for firms with more investment opportunities and more intangible assets [Axelson, 2010].

In examining the relationship between leverage and company profitability, many studies revealed a negative relationship between profitability and leverage [Abor, 2005; Sandhar, Janglani, 2013]. The authors indicated that large profitable companies prefer to have lower levels of debt. Firms with high profit levels maintain lower levels of debt as they can just use their internal sources. Some authors suggest that the negative relationship between leverage and growth exists because firms with high leverage might not be able to take advantage of growth opportunities [Myers, 1977]. In the growth stage, a company with extensive investment opportunities may experience a negative debt effect because of underinvestment [McConnell, Servaes, 1995]. Some researchers found a positive relationship between profitability and leverage. Abor considers there to be a positive relationship between the ratio of short-term debt to total assets and profitability, but a negative association between the ratio of long term debt to total assets and profitability [Abor, 2005]. High levels of debt can be deferred from investing in projects with a negative net present value for companies with low investment opportunities in the decline stage.

Based on asymmetric information and signaling theorems, the authors consider that asymmetric information between managers and owners led to an imperfect pricing of loans, in which debt is considered as a positive signal of a high-quality firm. In this case, the relationship between debt and firm performance will be positive [Ross, 1977]. One of the latest studies about the relationship between capital structure, ownership and performance was written in 2014 [Wahba, 2014]. The authors focused on the influence of managerial ownership on debt and firm performance and argue that managerial ownership reduces the relationship between debt and firm performance. Some recent study results describe that there is a significant, negative relationship between financial leverage, one of the control variables used in the study and ROA, with a significant, positive relationship between financial leverage and Tobin's Q. 


\section{Ownership structure and company life cycle}

The main research focuses on three main aspects about the impact of ownership structure on a company's efficiency: the concentration of ownership, the role of property managers and the role of the state. The distribution of corporate control determines the characteristics of agency relations in the company and will, of course, have a different impact on the effectiveness of the various stages of the life cycle. Conflict between other economic agents brings with it the selection of ineffective policies and the discrimination of some stakeholders for the benefit of others.

When considering the impact of majority shareholders on a company's effectiveness, it is necessary to take into account various situations. In the first case, concentrated ownership turns the interest of the shareholders towards increasing the company's value, but it also stimulates them to increase control over the actions of the managers [La Porta, Lopez-De-Silanes, Shleifer, 1999]. This classic conflict between a manager and an owner is a low-level motivation for the manager to maximize the value of the company. According to Berle and Means, managers with fixed wages prefer to minimize their exertion in order to extract all the possible non-monetary benefits, such as increasing their level of knowledge at the expense of the company and finding out all kinds of sensitive information [Berle, Means, 1932].

On the other hand, a high level of concentration can disturb the laws of minority shareholders when there are few strategic shareholders in the company. A majority seeking to maximize their own income deprives minorities of their share of the residual income, influencing the decision-making process in the corporation [Burkart, Gromb, Panunzi, 1997]. Thus, agency costs may depend on the degree of ownership concentration. Next, a negative investigation of the concentration of ownership may bring a drop in share liquidity, which in turn affects the cost of the company's capital. Thus, the concentration of ownership may have a different impact on corporate performance. Some authors claim that concentrated ownership is related to a decrease in financing constraints for a company's operation in emerging markets [Khanna, Palepu, 2000]. Over the past twenty years, researchers have made a large number of models linking ownership structure with the indicators of corporate performance. The first non-monotonic dependence was observed by Morck, Shleifer and Vishny in 1988 [Morck, Shleifer, Vishny, 1988].

As mentioned earlier, there are three types of agency conflicts with the third being the agency conflict between shareholders and the government. This arises from a mismatch of goals and optimal levels of risk for such agents. The state as investor pursues a number of social purposes in addition to maximizing the value [Farag, Mallin, Ow-Yong, 2014]. The impact of ownership structure on efficiency is associated with the presence of conflict be- tween managers, majority shareholders, the state and the minority shareholders. The corporate governance system, which is also a key component of the financial architecture, is designed to smooth out the effects of such conflicts between stakeholders. The first empirical evidence of the influence of state ownership on the effectiveness of the company appeared in the twentieth century. It was this work, based on theoretical assumptions, in which the author suggested that state-owned companies would initially be less efficient than private ones [Alchian, 1965]. Several factors were identified, which explained the differences in efficiency between public and private companies [Stiglitz, 1988; Boycko, Shleifer, Vishny,1996; Grout, Martin, 2003;]. Revenues of state companies do not directly go to officials; first they go to the state budget and as a result, all of the officials are interested in maximizing the company's value and the profitability of its assets, which reduces the motivation level of managers. Such an inflexible system of corporate governance in state companies can decrease the efficiency of a company. If a private company would inefficiently be using their financial resources, the market may respond by making capital withdrawals from the company or its merger. The study of Goldeng, Grünfeld and Benito analyzed the differences between the efficiency of private and public companies in Norway, a country with a large share of state ownership [Goldeng, Grünfeld, Benito, 2004] The values of ROA and operating efficiency were used as an indicator of the company. The authors showed that state companies are less efficient than private ones. However, the latest empirical research findings for developing countries proved to be rather contradictory.

The share of institutional investors increased from $4 \%$ in 1960 to $25 \%$ at the end of 1990 . The influence of institutional investors on efficiency was relevant in the context of large companies, which was later confirmed by empirical research data. It is because of this fact that institutional investors are not risk averse that prevents them from investing in small companies. In 1975, U.A. McEachern defined a new type of ownership, which for the first time included institutional investors. [McEachern, 1975]. His study argues that the role of institutional investors is also to monitor the activities of managers. Some recent studies describe the positive relation between venture capital ownership and corporate governance. The authors focused on the two ideas that a high level of outside shareholders, such as with venture capital, leads to an effective corporate governance and that there is a significant positive relationship between corporate governance factors and financial performance [Farag, Mallin, OwYong, 2014].

Based on last year's analysis, three indicators of ownership structure have been chosen, which are the potential drivers of strategic effectiveness. These include the concentration of ownership, state ownership, and the ownership of institutional investors.

In the growth stages, a high concentration helps to improve the efficiency of decision-making and sustainability of the company [Shleifer, Vishny, 1997; Durnev, Kim, 
2005; López-Iturriaga, Lopez-de-Foronda, 2011]. In this case, the interests of the company owners and minority shareholders are likely to coincide, while the highest concentration of control can increase the interest of employer and its ability to effective monitor the actions of managers. However, with an increase in the concentration of ownership, such a high level of majority shareholders may have a negative effect on a company's performance since they can use the company's resources for personal purposes.

In the maturity stage, the interests of the majority and minority shareholders begin to diverge and the agency conflict begins to negatively influence efficiency. The majority can use a stable free cash flow for personal purposes, thereby exacerbating the second kind of agency conflict. In the future with an increase in the majority share, this effect disappears due to the fact that they cannot derive personal benefit at the expense of minority shareholders, since they own more than a substantial proportion of the shares.

Some researchers [Haskel, Pereira, Slaughter, 2007; Huang, Shiu, 2009] claim that foreign owners, who are not majority investors, help ease this agency conflict and thus are the guarantor of a balanced ownership structure, which has a positive impact on the strategic effectiveness of the company. However, such a high share of member ownership from the board of directors is an indicator of a penetration of majority shareholders in the company's management structure, which exacerbates the second type of agency conflict, and which thereby has a negative impact on the company's strategic effectiveness.

\section{Corporate governance and company life cycle}

The next component of a company's financial architecture is corporate governance and in particular, how the board of directors influences the company's performance. Usually, in management theory, the board of directors represents and protects the interests of the dispersed shareholders. The effectiveness of corporate governance depends on many factors and in particular, on compliance with corporate governance standards. Effective corporate governance is a signal to investors to buy shares for the implementation of long-term investments. This is due to the fact that corporate governance reduces the risk of crises or at least increases the probability of their successful resolution and it provides a "transparency" for relationships with shareholders and investors.

In the case analysis of corporate governance, there is a common position, which considers agency conflicts as the root causes and ways to resolve and mitigate them - as the content of corporate governance. A widespread understanding of corporate governance can be formulated as the set of processes by which resource providers ensure sufficient profitability of their investments in the form of financial capital [Shleifer, Vishny, 1997].

In different studies, there are different approaches with particular investigations on how to improve corporate governance. The universal approach can be effective because a general set of rules can be applied to many countries and to many companies in each country. In addition, we can say that the "local" corporate governance in different countries can be more effective because it will be more flexible. Now, there is evidence that using just one type is not always effective for all firms in all countries [Bebchuk, Hamdani, 2009; Brătianu, Pînzaru, 2015]. The optimal corporate governance will be different in developed and emerging markets. In 2011, Bernard and other researchers analyzed corporate governance in emerging markets and, for the data sample, chose BRIC countries. The results claimed that country characteristics have a strong impact on a company's market value and performance.

In some research, the contents of the boards of directors as a key body of corporate governance is considered by using tasks, which are a combination of control problems and the monitoring of management actions. The board of directors is considered as space for clashes of interests and as a body dedicated to balancing these. The works of Cadbury show a significant imbalance of power in the company regarding the dominance of management [Cadbury, 1993]. An effective mechanism to correct the imbalance was proposed filling the board of directors with a significant proportion of independent directors. In the case of a high concentration of ownership, independent directors have an important role in the procedure of control over managers and, moreover, independent directors are also the guarantors of the rights for the interests of minority shareholders [Filatotchev, Bishop, 2002].

Regarding the structure of the board, we have identified three groups of members of the board of directors: the executive directors, who combine the functions of a board of directors member and management functions, the foreign affiliated directors and the independent directors [Cadbury, 1993]. The concept of active involvement between the independent directors and the issues of internal distribution functions of the board, including the practice of a number of decisions being made only by independent directors, became the basis of a balanced system of corporate governance. Some authors have considered that the optimal number of directors is mostly for empirical academic studies [Goodstein, Gautam, Boeker, 1994; Forbes, Milliken, 1999; Golden, Zajac, 2001].

Discussions about intensifying the role of the board of directors led to the appearance of new approaches for comprehending the content of corporate governance. There is the position that the emergence of corporate governance, as well as the characteristics in its development, is due to the certain stages in the life cycle of a company. Pye and Pettigrew claim that there needs to be an empirical analysis of the changes in corporate governance functions when a company goes to the next life cycle stage [Pye, Pettigrew, 2005]. Researchers considered certain parts of a company's performance and the growth that would necessitate changes in instruments of corporate governance. A few previous studies investigated the role 
of governance mechanisms in solving conflicts of interest between shareholders and managers, and in increasing performance [Aydin, Sayim, Yalama, 2007; Cubbin, Leech, 1983; Jarboui, Forget, Boujelbene, 2014].

If we focus only on agency conflicts, we will not be able to explain the differences in mechanism between different companies and business environments. The dynamics of corporate governance in company should be researched. Filatochev, Toms and Wright [Filatochev, Toms, Wright, 2006] suggest that a set of corporate governance characteristics should change depending on the strategic shifts and the changing relations between the functions of the board of directors towards wealth-protection. The need for a dynamic corporate governance conception forms, taking into account the process of adapting the mechanisms to the changing problems of a company.

These problems, which were discussed in the analytical and empirical work about the activities and roles of boards of directors, have led to the need for a new instance in the understanding of corporate governance. Large shareholders, institutional investors, and board members should be involved in working on strategic decisions along with the management so as to be able to reduce strategic errors. These works have examined the impact of institutional investors on corporate governance from their effects on stock prices and profitability [Alves, Francisco, 2014; Jiambalvo, Rajgopal, Venkatachalam, 2002]. The results of the studies showed that the relation between corporate governance factors, the ROA and the market-based Tobin's Q is significant and positive. Such a relationship is similar to that of a performance increase by adopting corporate governance principles.

In the maturity stage, an increase in control over the actions of managers can be achieved through the expansion of the board of directors [Mak, Kusnadi, 2005]. Therefore, in the growth stage, the size of the board of directors should be positively related to performance, while in the rapid growth stage, a large board of directors will rather hamper the decision-making process. So during a company's decline stage, an increasing in the proportion of independent directors may be associated with a desire to supply a positive signal to inefficient companies about the quality of corporate governance.

After a literature review of the components of financial architectures, we were able to identify the main factors that influence a company's performance, which we will use for future empirical analysis. Financial leverage is the main factor of capital structure and can impact a company's performance and depending on the life cycle stage, it can have positive or negative impact on a company's performance. According to the results of recent studies, the main factors of ownership structure, which have an effect on companies, especially in emerging markets, have been identified as ownership concentration and state, institutional investors and insider owners. While, the factors of corporate governance are board size, state and independence.

\section{Research hypotheses}

Based on the literature review, we analyzed and classified the results of both previous and recent empirical studies in order to formulate hypotheses in which authors analyzed the influence of ownership structure, capital structure and corporate governance on the efficiency of the company. For the last few decades, different stylized models have been created to describe company performance, which includes many types of a company's characteristics such as the structure of governance, capital structure, and so on. As showed below in different studies, such models can explain the influence of only one or two of many company's characteristics. This leads us to the fact that there is no need to use an integrated approach like that of financial architecture.

The following hypotheses were formulated:

- H1: There are several sustainable types of financial architecture in emerging markets which differ significantly.

One of the most important issues in the area of finance is what strategies companies use to finance their activities in a company's life cycle. According to the explanation above, a company's life cycle can affect their capital structure decisions and selection, and a company's managers are looking to implement the best capital structure. Although, the subject of many previous studies was investigating the factors that affect the selection of capital structure, there are very few studies conducted on the effect of capital structure on the life cycle. Therefore, leverage has a different impact on the company's strategic performance depending on which stage of the life cycle the company is located.

Ownership structure optimization has been studied for the last 30 years focusing on such topics as insider ownership, state ownership and ownership concentration. As described earlier, the major mechanism of the performance effect of ownership structure is the agency conflicts between managers and shareholders, major and minor shareholders and the state. In the maturity stage, the majority and minority shareholders have different interests which means that the agent conflict starts to negatively affect company efficiency. State ownership and its efficiency have also been widely studied. It can be claimed that there is a strong positive relation between the level of state ownership and the company's performance.

Independent directors have a huge impact on the process of controlling managers, especially, in the case of a high concentration. The studies showed that the number of non-executive directors increases the value of shares. This positive correlation between independent directors and performance has been described in recent studies. According to the literature review of corporate governance, the main factors that had a significant impact on a company's performance have been defined as board size and independent directors.

Thus, the hypotheses about the influence of the characteristics of the board of directors on the strategic efficiency of companies are as follows: 
- H2: Financial leverage has a negative impact on company performance in the growth and maturity stages.

- H3: The size of the board has a positive impact on performance in all the life cycle stages.

- H4: In the growth stage, ownership concentration positively impacts performance.

\section{Methodology and Data}

\section{Data}

For this paper, the primary data consisted of non-financial companies in emerging markets, which prepared their financial reports according to the IFRS or US GAAP standards. We excluded financial companies because it was incorrect to compare them due to their different and unique capital structure and accounting. Emerging markets are fast growing and provide new investment opportunities, higher expected returns and, as said above, there is a lack of studies for corporate performance. Therefore, in order to analyze financial architecture, data was collected from these 11 countries in emerging market -

India, China, Russia, Poland, Greece, Hungary, Croatia, the Czech Republic, Turkey, Brazil and Mexico.

The sample data consists of 4,675 companies from the period from 2011-2015 and all the data is in US dollars. At first, the financial data was collected from the Capital IQ and Bloomberg database and additional information was collected from the financial reports of companies. The use of panel data is well suited for analyzing the dynamics of adjustments. Table 1 shows the distribution of companies by industry from the final sample. In this paper, the companies were divided at the life cycle stage for further analysis and therefore, we divided it in detail by industry. For the cluster analysis, we emitted the outliers due to missing information.

Table 1. Distribution of companies by industry

\begin{tabular}{|c|c|c|c|}
\hline Industry & $\mathbf{N}$ & Industry & $\mathbf{N}$ \\
\hline Advertising & 15 & Home Furnishings & 84 \\
\hline Aerospace/Defense & 23 & Household Products/Wares & 18 \\
\hline Agriculture & 51 & Housewares & 11 \\
\hline Airlines & 20 & Internet & 48 \\
\hline Apparel & 92 & Investment Companies & 1 \\
\hline Auto Manufacturers & 59 & Iron/Steel & 101 \\
\hline Auto Parts \& Equipment & 166 & Leisure Time & 45 \\
\hline Beverages & 66 & Lodging & 36 \\
\hline Biotechnology & 40 & Machinery-Construction \& Mining & 37 \\
\hline Building Materials & 180 & Machinery-Diversified & 183 \\
\hline Chemicals & 342 & Media & 63 \\
\hline Coal & 45 & Metal Fabricate/Hardware & 98 \\
\hline Commercial Services & 127 & Mining & 125 \\
\hline Computers & 89 & Miscellaneous Manufacturers & 147 \\
\hline Electric & 165 & Oil\& Gas & 58 \\
\hline Electrical Compo \& Equip & 176 & Oil \& Gas Services & 27 \\
\hline Electronics & 185 & Packaging \& Containers & 49 \\
\hline Energy-Alternate Sources & 36 & Pharmaceuticals & 256 \\
\hline Engineering \& Construction & 148 & Pipelines & 10 \\
\hline Entertainment & 40 & Real Estate & 1 \\
\hline Environmental Control & 48 & Retail & 190 \\
\hline Food & 174 & Semiconductors & 42 \\
\hline Forest Products \& Paper & 39 & Shipbuilding & 7 \\
\hline Gas & 16 & Software & 141 \\
\hline
\end{tabular}




\begin{tabular}{|c|c|c|c|}
\hline Industry & $\mathbf{N}$ & Industry & $\mathbf{N}$ \\
\hline Hand/Machine Tools & 36 & Storage/Warehousing & 4 \\
\hline Healthcare Products & 50 & Telecommunications & 124 \\
\hline Healthcare Services & 26 & Textiles & 72 \\
\hline Holding Companies-Divers & 51 & Toys/Games/Hobbies & 6 \\
\hline Home Builders & 9 & Transportation & 86 \\
\hline Water & 18 & Trucking \& Leasing & 1 \\
\hline
\end{tabular}

\section{Methodology}

This research was conducted in three stages. We identified the company's life cycle stages by comparing the rates of revenue growth versus the average rate of revenue growth in the industry. The second stage was a cluster analysis for each life cycle stage. The third stage was an implied regression analysis that described the impact of the financial architecture component on a company's performance in each cluster depending on the life cycle stages.

\section{The methodology of identifying a company's life cycle stages}

The life cycle of an organization (LCO) theory is essential as it investigates the relationship between capital and ownership structure, investments, corporate performance, etc. and the level of a company's development. The first researcher was Kenneth Boulding, who in 1950 suggested the concept of LCO. After this, the majority of theoretical and empirical studies were mostly based on the biological concept of the organization and that the passage of stages is a consistent and iterative process [Churchill, Lewis, 1983; Quinn, Cameron, 1983; Adizes, 1988].

The first phase in an empirical study is to define a company's life cycle stage. This is quite a challenge for researchers, as there is a complex selection of indicators that determine the stage of the life cycle. There are a great amount of papers that are devoted to the basic life cycle models. Greiner (1972), who introduced a description of five of the life cycle stages, made one of the first steps in this area. He claimed that all firms pass through similar phases of evolution and that specific entrepreneurial abilities are required at each stage. Every stage of evolution results in a management crisis, which is resolved through corporate governance reformation. Another approach was offered by Adizes (1979) and contains 10 stages of a firm's life cycle. There are some specific factors when defining the life cycle stage of a company. The literature provides various sets and process for detecting them. The main feature of research papers is that authors distinguish four life cycle stages: the start-up, growth, maturity, and decline stage. The most common method used in academic literature for finding out about life cycle stages is the ranking methodology [Aharony, Falk, Yehuda, 2006; Zhipeng Yan, Yan Zhao, 2006]. Whereas, the classic criteria for evaluating a company's business growth and the detection its life cycle stage usually references financial indicators such as the growth rate of the operating, investing and financing activities.
For this study, we selected the approach of comparing the growth rates of revenues at the average rate of revenue growth in the industry. Since companies cannot be public in the formation stage, there are only three stages of the life cycle that can be identified: growth, maturity and decline. This method compares the rate of revenue growth for two adjacent years to the industry growth pace that the company belongs to. If the company's growth rate in both periods is higher than the average growth rate of the relevant sector, then the company belongs in the growth stage. If the pace of growth in the previous period is close to the market average, but lower than the average growth rate of the relevant sector in the second period, then the company belongs in the stage of maturity. If the rate of growth for two consecutive periods were below the average rate of growth of the industry, then the company belongs in the decline stage. However, this approach has some disadvantages. First, a company's growth rates cannot explicitly point out life cycle stages. Also, the application of the other approaches is complicated due to the lack of financial information for a long period.

\section{Cluster analysis}

For the next stage, after determining a company's life cycle stages, there will be three samples: companies in the growth and maturity stage with the third sample including companies in the decline stage.

Cluster analysis is an aggregate of many algorithms and methods of grouping a set of objects in similar categories. In all cases, using cluster analysis allows the detection of a data structure, regardless of any initial knowledge of their nature [Pivoňka, Löster, 2013]. When using cluster analysis in empirical research, it first needs to be determined which approach will be used: the hierarchical or the sectioned. While the latter approach allows you to split data into mutually exclusive groups (clusters), the former allows you to build a hierarchy of clusters.

For future analysis, we chose to use hierarchical approach to determine sustainable types of financial architecture for each sample. The following criteria for corporate financial architecture will be used for data clustering:

- Capital structure variables: Total debt ratio calculated as the total interest-bearing debt with the sum of the total interest-bearing debt and the book value of equity; 
- Ownership variables: ownership concentration calculated as the share of three largest shareholders; institutional investor measured as the share of equity held by institutional investors such as banks, private equity funds, high funds, pension funds, etc. from developed capital markets;

- Variables for board of directors: the total number of the board members; independency rate measured as the ratio of the number of independent directors to the total number of board members.

In hierarchical methods, it is necessary to determine not only the distance between observations, but also the distance between clusters. For our analysis, we used the Ward method. The initial distances between clusters in the Ward method are calculated by Euclid's formula (1), which determines the distance between the points.

$d_{i j}=\left\|X_{i}-X_{j}\right\|^{2}$.
After determining the clusters, we analyzed firm performance for each cluster which includes market performance measured as the Tobin's Q coefficient (market value of equity to book value of equity ratio), return on equity (ROE), return on total assets (ROA) and TSR (total shareholder return). The next move was to check whether the same firms were clustered in the same way from year to year. Thirdly, we checked whether the firms from one industry were collected in one cluster or not.

\section{Results and discussion Results of defining the life cycle stages}

The primary sample consisted of 4,678 companies, but after removing all the companies with omitted data, the final sample included 1,637 companies. Using the Cao approach where a company's last two years of growth is compared to the growth in the industry, we divided this sample into three life cycle stages.

Figure 1. Distribution by life cycle stages

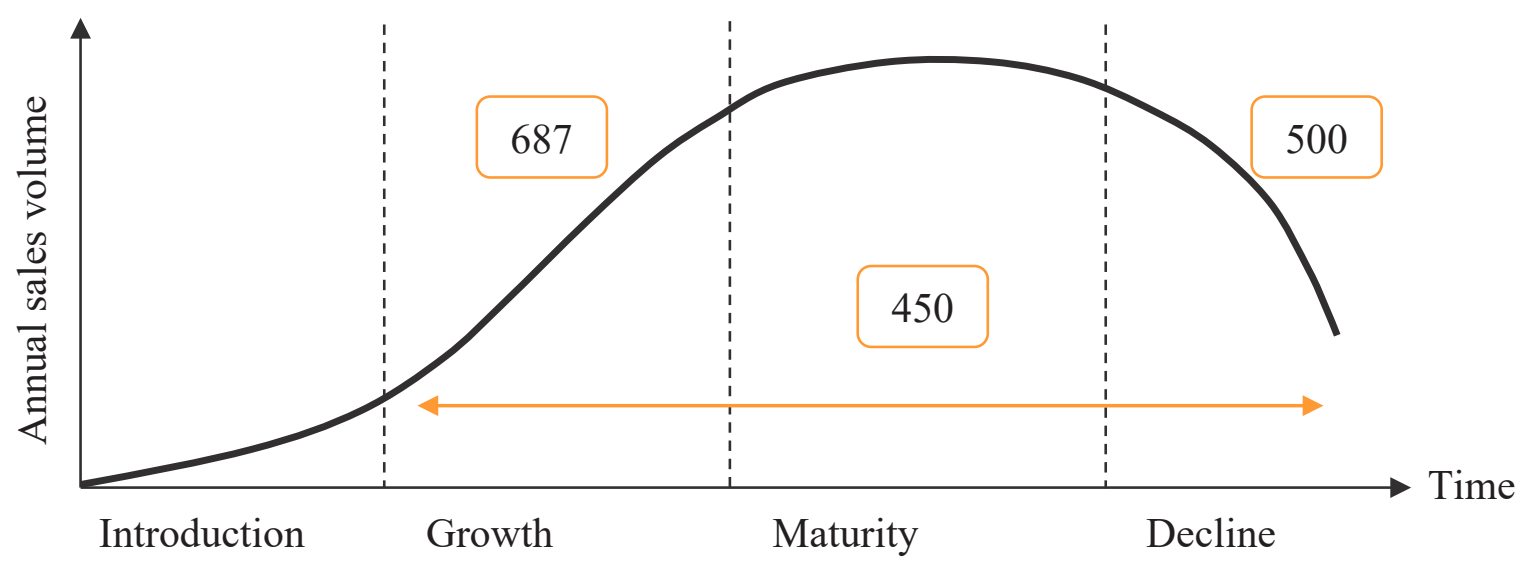

Figure 1 describes the distribution of companies. The results show that the number of companies in the growth stage is more than that in the mature or decline stage and it can indicate a positive relationship between the transparency of the information provided and the rate of growth:

- $\quad$ Growth stage 687;

- Maturity stage 450;

- Decline stage 500 .

The next step after data collecting is clearing the outliers by using criteria equal to the standard deviation of the outlier: Annual sales volume

$T=\frac{\widehat{X}_{i}-\mu}{\sigma} \geq T_{s t}$.

$\mathrm{T}$ - the criteria for outliers.

$\widehat{X}_{i}$ - the extra value of the characteristic (very large or very small).

$\mu, \sigma-$ average and sigma calculated for the sample including the outliers.
$T_{s t}$ - determined according to the Student distribution table.

Table (2) represents the final sample of our analysis and features companies distributed by countries and life cycle stage. A large number of companies was omitted from the sample due to the lack of information about corporate governance and ownership structure.

\section{Results of the cluster analysis}

In the second stage of our analysis, we used the SPSS program and all the variables from Table (2) to identify the number and type of different time period clusters in each life cycle stage. The clusters are persistent and stable from the beginning to the end of the period. Furthermore, the companies show almost no movement from cluster to cluster across the time of analysis. The analysis of the industry structure of the clusters revealed no industry effects in the cluster formation.

\section{Growth stage}

The following features characterize the clusters in the growth stage. 
Table 2. 2011-2015 Descriptive statistics for clusters in the growth stage

\begin{tabular}{|c|c|c|c|c|c|c|c|c|c|}
\hline Cluster & Var & $\mathbf{Q}$ & Lev & Bsize & Ind_perc & G_own & Instit & Ins_own & $\mathrm{OC}$ \\
\hline \multirow{3}{*}{1} & № & 332 & 332 & 332 & 332 & 332 & 332 & 332 & 332 \\
\hline & Mean & 3,0 & 0,54 & 8,9 & 0,45 & 0,13 & 0,15 & 0,2 & 0,5 \\
\hline & St.dev. & 2,5 & 0,79 & 2,2 & 0,14 & 0,18 & 0,17 & 0,25 & 0,25 \\
\hline \multirow{3}{*}{2} & № & 283 & 283 & 283 & 283 & 283 & 283 & 283 & 283 \\
\hline & Mean & 2,0 & 0,68 & 0,08 & 0,44 & 0,08 & 0,1 & 0,18 & 0,49 \\
\hline & St.dev. & 1,3 & 1,33 & 0,02 & 0,15 & 0,16 & 0,17 & 0,24 & 0,25 \\
\hline \multirow{3}{*}{3} & № & 71 & 71 & 71 & 71 & 71 & 71 & 71 & 7 \\
\hline & Mean & 5,0 & 0,28 & 9 & 0,46 & 0,15 & 0,18 & 0,16 & 0,5 \\
\hline & St.dev. & 3,1 & 0,92 & 0,02 & 0,16 & 0,22 & 0,12 & 0,2 & 0,27 \\
\hline
\end{tabular}

Table 3. 2011-2015 Descriptive statistics for clusters in the maturity stage

\begin{tabular}{|c|c|c|c|c|c|c|c|c|c|}
\hline Cluster & Var & $\mathbf{Q}$ & Lev & Bsize & Ind_perc & G_own & Instit & Ins_own & $\mathrm{OC}$ \\
\hline \multirow{3}{*}{1} & № & 177 & 177 & 177 & 177 & 177 & 177 & 177 & 177 \\
\hline & Mean & 3,6 & 0,10 & 9 & 0,38 & 0,10 & 0,20 & 0,29 & 0,29 \\
\hline & St.dev. & 7,9 & 0,24 & 3 & 0,14 & 0,12 & 0,15 & 0,27 & 0,14 \\
\hline \multirow{3}{*}{2} & № & 234 & 234 & 234 & 234 & 234 & 234 & 234 & 234 \\
\hline & Mean & 2,8 & 0,06 & 9 & 0,36 & 0,13 & 0,18 & 0,18 & 0,32 \\
\hline & St.dev. & 2,7 & 0,13 & 3 & 0,13 & 0,18 & 0,17 & 0,20 & 0,18 \\
\hline \multirow{3}{*}{3} & № & 88 & 88 & 88 & 88 & 88 & 88 & 88 & 88 \\
\hline & Mean & 2,7 & 0,2 & 10 & 0,34 & 0,16 & 0,18 & 0,20 & 0,33 \\
\hline & St.dev. & 2,4 & 0,16 & 3 & 0,14 & 0,20 & 0,15 & 0,24 & 0,17 \\
\hline
\end{tabular}

As we can see, all three clusters are different and show different information.

Cluster 1: The companies in this cluster experience are companies with sustainable growth. This cluster is characterized by Tobin's Q coefficient equal to three. The leverage level is approximately $50 \%$ in the stable periods and the highest concentration.

Cluster 2: The second cluster is characterized by having the largest level of leverage. As we can see, state ownership and institutional investors is the lowest among the three clusters.

Cluster 3: Companies in this cluster are characterized by having the largest level of independence directors and governance ownership, and the lowest level of debt, leading to the highest ROE indicators with average profitability ratios.

\section{Maturity stage}

Cluster 1: This cluster shows Tobin's Q coefficient approximately equal to four. The leverage level is $10 \%$ during stable periods and the lowest concentration when compared to the other two clusters. There is a lower percent of governance ownership for all the clusters.

Cluster 2: The lowest leverage level and a low inside ownership characterize this cluster. The low rates of return on total capital together with the growth rate decreases during this period and it has the largest number of independent directors.

Cluster 3: Companies in this cluster are characterized by an average insider ownership and have the highest level of ownership concentration along with an average level of debt. 


\section{Decline stage}

Table 4. 2011-2015 Descriptive statistics for clusters in the decline stage

\begin{tabular}{|c|c|c|c|c|c|c|c|c|c|}
\hline Cluster & Var & $\mathbf{Q}$ & Lev & Bsize & Ind_perc & G_own & Instit & Ins_own & $\mathrm{OC}$ \\
\hline \multirow{3}{*}{1} & № & 54 & 54 & 54 & 54 & 54 & 54 & 54 & 54 \\
\hline & Mean & 1,34 & 0,2 & 9 & 0,37 & 0,1 & 0,03 & 0,23 & 0,44 \\
\hline & St.dev. & 1,7 & 132 & 2 & 0,16 & 0,2 & 0,25 & 0,24 & 0,18 \\
\hline \multirow{3}{*}{2} & № & 284 & 284 & 284 & 284 & 284 & 284 & 284 & 284 \\
\hline & Mean & 3,2 & 0,1 & 9 & 0,4 & 0,15 & 0,09 & 0,15 & 0,22 \\
\hline & St.dev. & 2,1 & 51 & 2 & 0,12 & 0,2 & 0,11 & 0,19 & 0,13 \\
\hline \multirow{3}{*}{3} & № & 109 & 109 & 109 & 109 & 109 & 109 & 109 & 109 \\
\hline & Mean & 2,01 & 0,1 & 9 & 0,38 & 0,11 & 0,07 & 0,48 & 0,34 \\
\hline & St.dev. & 1,23 & 3 & 2 & 0,1 & 0,2 & 0,09 & 0,18 & 0,13 \\
\hline
\end{tabular}

Cluster 1: The first cluster shows the largest ownership concentration and lowest coefficient for Tobin's Q. Also, we can see a low level of governance ownership.

Cluster 2: In this cluster, there is the highest coefficient for Tobin's Q, the lowest level of insider ownership and the highest level of independent directors.

Cluster 3: Companies in this cluster are characterized by having a large number of independent directors and a low level of governance ownership.

Thus, we believe that the combined analysis of market performance, growth rates and profitability measures leads us to the conclusion that the clusters are sorted from most to least efficient. In the growth stage, the third cluster shows the highest Tobin's Q ratio and also has a high level of concentration and a high level of independent directors. In the maturity stage, the first cluster defines the high Tobin's Q coefficient with a low level of leverage and state ownership. To check the hypotheses and to describe an accurate relationship of financial architecture to component relation, we should provide a regression analysis. Using a regression analysis on each cluster will remove the most effective cluster in each life cycle stage.

Emerging markets are interesting to analyze because they have some specific features when compared to developed markets. In addition, the macroeconomic instability and the high influx that is typical for emerging markets leads to investor's uncertainty. However, these companies often have weak corporate governance that appears to be one of the important factors of capital structure choice. In emerging markets, we see a higher level of ownership concentration and a lower level of institutional investors and, as we mentioned above, many researchers were analyzing the possibility of such results. Current results can be obtained where there is no dependence between country specific characteristics and cluster formation because the financial architecture of countries in emerging markets is very close. To be absolutely sure of accuracy in results for future analysis, we are going to introduce a deeper country analysis by comparing the financial architecture of companies in the emerging market and the developed market.

\section{Conclusions}

The results obtained in this study are of a highly practical importance. In this paper, we have identified and formed the key factors for company growth, as well as its influence. The definition of these factors is necessary for the management, shareholders and the directors regarding the decision-making process. From the above examples, it can be observed that it is usually difficult for companies to move from one life cycle to another. Due to choosing the wrong financial architecture, companies decry their performance. There is high competition in the emerging markets and a lack of analysis in this area.

Using a cluster analysis on each life cycle stage, we suggest three types of clusters. Such cluster analysis describes the different. effective types of financial architecture in emerging markets. We described the most sustainable types of financial architecture. An analysis of the dynamic cluster results suggests the identification of trends for non-financial solutions in emerging markets. After the cluster analysis, we also used a panel regression analysis to check the effectiveness of financial architecture clusters. It was conducted on each life cycle stage for each cluster.

According to our results, financial leverage has a negative impact on companies in all life cycle stages. However, in the decline stage, there was not any significant impact on the firm performance. It is obvious that companies in the two early life cycle stages should sustain low leverage. Increasing the leverage makes the management more conservative, which seems to reduce the propensity to be strategically opportunistic, which is something that is often required to deliver revenue growth. Leverage constricts revenue growth, which leads to a worse share-price 
performance on average. Corporate governance is one of the main components of financial architecture showing a common significant positive and negative influence on company efficiency and their result. In all three stages, board size has a positive impact, but this can be explained by the fact that the outliers were emitted from the sample and that the average size is nine. During analysis of companies in the growth stage, it became clear that independence could also negatively affect performance. Ownership structure has a different impact depending the life cycle stages and their factors. One of main factors, and the one least analyzed, is that of institutional investors. Regression analysis defines the positive influence of institutional investors on company efficiency. Institutional turnover in most stocks is quite low because it takes a great deal of time and money to research a company and to build a position in it. In any case, when funds do obtain large positions, they want to do their utmost to make sure their investments do not go awry. To that end, they will often maintain a dialogue with the company's board of directors.

One of the main differences of our study is that it used a cluster analysis to model performance, whereas, in future analysis, we need to use a traditional regression analysis to identify the impact of financial architecture characteristics on performance. As said above, a company is a dynamic system and during the period it goes through the different stages of the life cycle, it undergoes significant changes while the financial architecture of the company also changes over the life cycle, adjusting to fit the goals and needs of the company.

\section{References}

Abor, J. (2005) The Effect of Capital Structure on Profitability: An Empirical Analysis of Listed Firms in Ghana. The Journal of Risk Finance, 6, 5, pp. 438-445.

Adizes, I. (1979) Organizational Passages — Diagnosing and Treating Lifecycle Problems of Organizations. Organizational Dynamics, 8, 1, pp. 3-25.

Adizes, I. (1988) Corporate Lifecycles: How and Why Corporations Growth and Die and What to Do about It. Englewood Cliffs, NJ: Prentice-Hall.

Aharony, J., Falk, H., Yehuda, N. (2006) Corporate Life Cycle and the Relative Value-Relevance of Cash Flow Versus Accrual Financial Information [e-resource]. URL: https://www.researchgate.net/publication/228170690_ Corporate_Life_Cycle_and_the_Value_Relevance_of_Cash_Flow_versus_Accrual_Financial_Information (accessed: 25.12.2017).

Alchian, A.A. (1965) Some Economics of Property Rights. Il Politico, 30, 4, pp. 816-829.

Alves, P., Francisco, P. (2014) The Impact of Institutional Environment on the Capital Structure of Firms during Recent Financial Crises. The Quarterly Review of Economics and Finance, 57, C, pp. 129-146.
Amidu, M. (2007) Determinants of Capital Structure of Banks in Ghana: An Empirical Approach. Baltic Journal of Management, 2, 1, pp. 67-79.

Aydin, N., Sayim, M., Yalama, A. (2007). Foreign Ownership and Firm Performance: Evidence from Turkey. International Research Journal of Finance and Economics, 11, pp. 103-111.

Axelson, U. (2010) Borrow Cheap, Buy High? The Determinants of Leverage and Pricing in Buyouts / Axelson, U., Jenkinson, T., Strömberg, P., Weisbach, M.S.: NBER Working Paper No. 15952. Cambridge, MA: NBER.

Baker, M., Wurgler, J. (2002) Market Timing and Capital Structure. Journal of Finance, 57, 1, pp. 1-32.

Baltaci, N., Ayaydin, H. (2014) Firm, Country and Macroeconomic Determinants of Capital Structure: Evidence from Turkish Banking Sector. EMAJ: Emerging Markets Journal, 3, 3, pp. 47-58.

Bebchuk, L.A., Hamdani, A. (2009) The Elusive Quest for Global Governance Standards. University of Pennsylvania Law Review, 157, pp. 1263-1316.

Berle, A., Means, G. (1932) The Modern Corporation and Private Property. N.Y.: Macmillan.

Boycko, M., Shleifer, A., Vishny, R. (1996) A Theory of Privatization. The Economic Journal, 106, 435, pp. 309-319.

Brătianu, C., Pînzaru, F. (2015). Challenges for the University Intellectual Capital in the Knowledge Economy. Management Dynamics in the Knowledge Economy, 3, 4, pp. 609-627.

Burkart, M., Gromb, D., Panunzi, F. (1997) Large Shareholders, Monitoring and the Value of the Firm. Quarterly Journal of Economics, 112, 3, pp. 693-728.

Cadbury, A. (1993) Highlights of the Proposals of the Committee on Financial Aspects of Corporate Governance / D.D. Prentice, P.R.J. Yolland (eds.). Oxford: Clarendon Press. (Contemporary Issues in Corporate Governance).

Canarella, G., Nourayi, M., Sullivan, M.J. (2014) An Alternative Test of the Trade-off Theory of Capital Structure. Contemporary Economics, 8, 4, pp. 365-386.

Chung-Te Chang (2014) The Activation of the Decapping Enzyme DCP2 by DCP1 Occurs on the EDC4 Scaffold and Involves a Conserved Loop in DCP1 / Chung-Te Chang, Bercovich, N., Loh, B. [et al.]. Nucleic Acids Research, 42, 8, pp. 5217-5233.

Churchill, N.C., Lewis, V.L. (1983) The Five Stages of Small Business Growth. Harvard Business Review, 61, 3, pp. $30-50$.

Cubbin, J., Leech, D. (1983) The Effect of Shareholding Dispersion on the Degree of Control in British Companies: Theory and Measurement. Economic Journal, 93, 37, pp. 351-369. 
DeAngelo, H., Roll, R. (2015) How Stable Are Corporate Capital Structures? Journal of Finance, 70, 1, pp. 373-418.

Dickinson, V. (2011) Cash Flow Patterns as a Proxy for Firm Life Cycle. The Accounting Review, 86, 6, pp. 1969-1994.

Durnev, A., Kim, E.H. (2005) To Steal or Not to Steal: Firm Attributes, Legal Environment, and Valuation. The Journal of Finance, 60, 3, pp. 1461-1493.

Farag, H., Mallin, Ch., Ow-Yong, K. (2014) Governance, Ownership Structure, and Performance of Entrepreneurial IPOs in Aim Companies. Corporate Governance: An International Review, 22, 2, pp. 100-115.

Fernandes, N. (2011) Global Convergence of Financing Policies: Evidence for EM firms. Journal of International Business Studies, 42, 8, pp. 1043-1059.

Filatotchev, I., Bishop, K. (2002) Board Composition, Share Ownership, and Underpricing' of UK IPO Firms. Strategic Management Journal, 23, 10, pp. 941-955.

Filatotchev, I., Toms, S., Wright, M. (2006) The Firm's Strategic Dynamics and Corporate Governance LifeCycle. International Journal of Managerial Finance, 2, 4, pp. 256-279.

Forbes, D.P., Milliken, F. (1999) Cognition and Corporate Governance: Understanding Board of Directors as Strategic Decision-Making Groups. Academy of Management Review, 24, 3, pp. 489-505.

Frank, M.Z., Goyal, V.K. (2008). Trade-Off and Pecking Order Theories of Debt. In: B. Espen Eckbo (ed.). Handbook of Empirical Corporate Finance. Elsevier, ch. 12, pp. 135-202.

Gilson, R.J., Gordon, J.N. (2003) Controlling Controlling Shareholders: Columbia Law and Economics Working Paper No. 228; Stanford Law and Economics Olin Working Paper, No. 262. URL: https://dx.doi.org/10.2139/ ssrn.417181 (accessed: 19.12.2017).

Golden, B.R., Zajac, E.J. (2001) When Will Boards Influence Strategy? Inclination $\times$ Power $=$ Strategic Change. Strategic Management Journal, 22, 12, pp. 1087-1111.

Goldeng, E., Grünfeld, L.A., Benito, G.R.G. (2004) The Inferior Performance of State Owned Enterprises: Is it due to Ownership or Market Structure: NUPI Working Paper No. 663-2004. Oslo: Norsk Utenrikspolitisk Institutt.

Goodstein, J., Gautam, K., Boeker, W. (1994) The Effects of Board Size and Diversity on Strategic Change. Strategic Management Journal, 15, 3, pp. 241-250.

Greiner, L.E. (1972) Evolution and Revolution as Organizations Grow. Harvard Business Review, 50, 4, pp. 37-46.

Greiner, L.E. (1998) Evolution and Revolution as Organizations Grow. Harvard Business Review, 76, 3, pp. 55-68.
Grout, P.A., Martin, S. (2003) The Assessment: Financing and Managing Public Services. Oxford Review of Economic Policy, 19, 2, pp. 215-234.

Halov, N., Heider, F. (2011) Capital Structure, Risk and Asymmetric Information. Quarterly Journal of Finance, 1, 4, pp. 767-809.

Haskel, J., Pereira, S., Slaughter, M. (2007) Does Inward Foreign Direct Investment Boost the Productivity of Domestic firms? Review of Economics and Statistics, 89, 3, pp. 482-477.

Hermalin, B.E., Weisbach, M.S. (1991) The Effects of Board Composition and Direct Incentives in firm Performance. Financial Management, 20, 4, pp. 101-112.

Huang, R.D., Shiu, C.Y. (2009) Local Effects of Foreign Ownership in an Emerging Financial Market: Evidence from Qualified Foreign Institutional Investors in Taiwan. Financial Management, 38, 3, pp. 567-602.

Ivashkovskaya, I.V., Konstantinov, G.N., Filonovich, S.R. (2008) The Effect of the Corporate Lifecycle on Corporate Governance. In: The Canada-Russia Corporate Governance Program, 2000-2006: History, Papers, Cases and Prospects. Toronto: Schulich School of Business, pp. $247-269$.

Ivashkovskaya, I.V., Yangel, D.O. (2007) Organization Life Cycle and Growth Aggregate. Online Journal "Corporate Finance", 4, pp. 97-110.

Jarboui, S. (2016) Managerial Psychology and Transport Firms Efficiency: A Stochastic Frontier Analysis. Review of Managerial Science, 10, 2, pp. 365-379.

Jarboui, S., Forget, P., Boujelbene, Y. (2014) Inefficiency of Public Road Transport and Internal Corporate Governance Mechanisms. Case Studies on Transport Policy, 2, 3, pp. 153-167.

Jensen, M., Meckling, W. (1976) Theory of the Firm: Managerial Behavior, Agency Costs and Ownership Structure. Journal of Financial Economics, 3, 4, pp. 305-360.

Jiambalvo, J., Rajgopal, S., Venkatachalam, M. (2002) Institutional Ownership and the Extent to Which Stock Prices Reflect Future Earnings. Contemporary Accounting Research, 19, 1, pp. 117-145.

Khanna, T., Palepu, K. (2000) Is Group Affiliation Profitable in Emerging Markets? An Analysis of Diversified Indian Business Groups. The Journal of Finance, 55, 2, pp. 867-891.

López-Iturriaga, F.J., Lopez-de-Foronda, Ó. (2011) Corporate Social Responsibility and Large Shareholders: An Analysis of European Multinational Enterprises. Transnational Corporations Review, 3, 3, pp. 17-33.

La Porta, R., Lopez-De-Silanes, F., Shleifer, A. (1999) Corporate Ownership around the World. The Journal of Finance, 54, 2, pp. 471-831. 
Lang, L., Ofek, E., Stulz, R.M. (1995) Leverage, Investment, and Firm Growth: NBER Working Paper No. 5165. Cambridge, MA: NBER.

Mak, Y.T., Kusnadi, Y. (2005) Size Really Matters: Further Evidence on the Negative Relationship between Board Size and Firm Value. Pacific-Basin Finance Journal, 13, 3, pp. 301-318.

McConnell, J.J., Servaes, H. (1995) Additional Evidence on Equity Ownership and Corporate Value. Journal of Financial Economics, 27, 2, pp. 595-612.

McEachern, W. (1975) Managerial Control and Performance. Toronto: Lexington Books.

Merika, A. (2015) The Relationship between Business Cycles and Capital Structure Choice: The Case of the International Shipping Industry / Merika, A., Theodoropoulou, S., Triantafyllou, A., Laios, A. The Journal of Economic Asymmetries, 12, pp. 92-99

Modigliani, F., Miller, M. (1958) The Cost of Capital, Corporation Finance, and the Theory of Investment. American Economic Review, 48, 3, pp. 261-297.

Morck, R., Shleifer, A., Vishny, R. (1988) Management Ownership and Market Valuation: An Empirical Analysis. Journal of Financial Economics, 20, 1-2, pp. 293-315.

Myers, S.C. (1977) Determinants of Corporate Borrowing. Journal of Financial Economics, 5, 2, pp. 147-175.

Myers, S.C. (1984) The Capital Structure Puzzle. Journal of Finance, 39, 3, pp. 575-592.

Myers, S.C. (1999) Financial Architecture. European Financial management, 5, 2, pp. 133-141.

Myers, S.C. (2001) Capital Structure. Journal of Economic Perspectives, 15, 2, pp. 81-102.

Pivoňka, T., Löster, T. (2013) Clustering of EU Countries Before and During Crisis. In: T. Löster, T. Pavelka (eds.), The 7th International Days of Statistics and Economics (Prague, September 19-21, 2013), pp. 1110-1121.

Pye, A., Pettigrew, A. (2005) Studying Board Context, Process and Dynamics: Some Challenges for the Future. British Journal of Management, 16, s1, pp. S27-S38.

Quinn, R.E., Cameron, K. (1983) Organizational Life Cycles and Shifting Criteria of Effectiveness: Some Preliminary Evidence. Management Science, 29, 1, pp. 33-51.

Ross, S. (1977) The Determination of Financial Structure: The Incentive-Signalling Approach. The Bell Journal of Economics, 8, 1, pp. 23-40.

Sandhar, S.K., Janglani, S. (2013) A Study on Liquidity and Profitability of Selected Indian Cement Companies:

A Regression Modeling Approach. International Journal of Economics, Commerce and Management, 1, 1, pp. 1-24.

Shleifer, A., Vishny, R.W. (1997) A Survey of Corporate Governance. The Journal of Finance, 52, 2, pp. 737-783.
Shyam-Sunder, L., Myers, S.C. (1999) Testing Static Trade-off against Pecking Order Models of Capital Structure. Journal of Financial Economics, 51, 2, pp. 219-244.

Stepanova, A., Balkina, E. (2013) Corporate Financial Architecture at Different Lifecycle Stages: Performance Effect in Russia. Journal of Corporate Finance Research, 3, pp. $4-20$.

Stiglitz, J. (1988) Economics of the Public Sector. 2nd ed. L.: Norton \& Company.

Stulz, R.M. (1990) Managerial Discretion and Optimal Financing Policies. Journal of Financial Economies, 26, 1, pp. 3-27.

Wahba, H. (2014) Capital Structure, Managerial Ownership and Firm Performance: Evidence from Egypt. Journal of Management \& Governance, 18, 4, pp. 1041-1061.

Zhipeng Yan, Yan Zhao (2006) A New Methodology of Measuring Corporate Life Cycle Stages. International Journal of Economic Perspectives, Forthcoming. URL: https://papers.ssrn.com/sol3/papers.cfm?abstract_ $\mathrm{id}=893826$ (accessed: 25.12.2017). 


\section{Appendix: Descriptive statistics of the sample}

Table A1. Growth stage cluster 1

\begin{tabular}{|c|c|c|c|c|c|c|}
\hline Variable & & Mean & Std. dev. & Min & $\operatorname{Max}$ & Observations \\
\hline \multirow[t]{3}{*}{ tobin_q } & overall & 2.399988 & 1.523554 & 0.44 & 13.01 & $\mathrm{~N}=1645$ \\
\hline & between & & 1.260341 & 0.586 & 7.726 & $\mathrm{n}=329$ \\
\hline & within & & 0.8582674 & 0.8720122 & 9.863988 & $\mathrm{~T}=5$ \\
\hline \multirow[t]{3}{*}{ tsr } & overall & 21.74362 & 205.6867 & -4.07 & 7787.54 & $\mathrm{~N}=1645$ \\
\hline & between & & 141.3555 & -2.21 & 2417.572 & $\mathrm{n}=329$ \\
\hline & within & & 149.5802 & -1594.728 & 5391.712 & $\mathrm{~T}=5$ \\
\hline \multirow[t]{3}{*}{ lev } & overall & 0.5933313 & 1.031405 & -12.85 & 18.13 & $N=1645$ \\
\hline & between & & 0.8353797 & -1.906 & 5.978 & $\mathrm{n}=329$ \\
\hline & within & & 0.6063286 & -10.35067 & 12.74533 & $\mathrm{~T}=5$ \\
\hline \multirow[t]{3}{*}{ board } & overall & 8.84924 & 2.192751 & 4 & 20 & $N=1645$ \\
\hline & between & & 2.06389 & 4.4 & 19.2 & $\mathrm{n}=329$ \\
\hline & within & & 0.7475833 & 4.84924 & 12.04924 & $\mathrm{~T}=5$ \\
\hline \multirow[t]{3}{*}{ pct_in $\sim t$} & overall & 0.4480912 & 0.1484482 & 0 & 1 & $\mathrm{~N}=1645$ \\
\hline & between & & 0.1359434 & 0 & 0.786 & $\mathrm{n}=329$ \\
\hline & within & & 0.0600101 & -0.0079088 & 0.9160912 & $\mathrm{~T}=5$ \\
\hline \multirow[t]{3}{*}{ state } & overall & 0.1226565 & 0.2045378 & 0 & 0.99 & $N=1645$ \\
\hline & between & & 0.2029279 & 0 & 0.938 & $\mathrm{n}=329$ \\
\hline & within & & 0.0274987 & -0.0773435 & 0.5506565 & $\mathrm{~T}=5$ \\
\hline \multirow[t]{3}{*}{ govern $\sim \mathrm{n}$} & overall & 0.0212888 & 0.0352853 & 0 & 0.15 & $\mathrm{~N}=1645$ \\
\hline & between & & 0.0350177 & 0 & 0.15 & $\mathrm{n}=329$ \\
\hline & within & & 0.0046691 & -0.0147112 & 0.0612888 & $\mathrm{~T}=5$ \\
\hline \multirow[t]{3}{*}{ bank_own } & overall & 0.0762128 & 0.0977947 & -0.02 & 0.95 & $N=1645$ \\
\hline & between & & 0.0935735 & -0.006 & 0.81 & $\mathrm{n}=329$ \\
\hline & within & & 0.0287945 & -0.2517872 & 0.3802128 & $\mathrm{~T}=5$ \\
\hline \multirow[t]{2}{*}{ instit $\sim t$} & overall & 0.154845 & 0.1632265 & 0 & 1.53 & $\mathrm{~N}=1645$ \\
\hline & between & & 0.1527439 & 0 & 0.906 & $\mathrm{n}=329$ \\
\hline
\end{tabular}




\begin{tabular}{|c|c|c|c|c|c|c|}
\hline \multirow[t]{2}{*}{ Variable } & & Mean & Std. dev. & Min & $\operatorname{Max}$ & Observations \\
\hline & within & & 0.0580425 & -0.351155 & 0.778845 & $\mathrm{~T}=5$ \\
\hline \multirow[t]{3}{*}{ insider } & overall & 0.1923951 & 0.2293182 & -0.13 & 0.9 & $N=1645$ \\
\hline & between & & 0.2219285 & -0.002 & 0.83 & $\mathrm{n}=329$ \\
\hline & within & & 0.0587744 & -0.2816049 & 0.6043952 & $\mathrm{~T}=5$ \\
\hline \multirow[t]{3}{*}{ concen $\sim \mathrm{n}$} & overall & 0.5089362 & 0.2536265 & 0 & 0.98 & $\mathrm{~N}=1645$ \\
\hline & between & & 0.253908 & 0 & 0.98 & $\mathrm{n}=329$ \\
\hline & within & & 0.0037404 & 0.4889362 & 0.5289362 & $\mathrm{~T}=5$ \\
\hline \multirow[t]{3}{*}{ roa } & overall & 0.0634833 & 0.0779417 & -0.58 & 0.67 & $\mathrm{~N}=1645$ \\
\hline & between & & 0.0612585 & -0.146 & 0.32 & $\mathrm{n}=329$ \\
\hline & within & & 0.0482849 & -0.4025167 & 0.6014833 & $\mathrm{~T}=5$ \\
\hline \multirow[t]{3}{*}{ roe } & overall & 0.1076474 & 0.1722938 & -2.33 & 1.21 & $N=1645$ \\
\hline & between & & 0.1216966 & -0.726 & 0.458 & $n=329$ \\
\hline & within & & 0.1221111 & -1.664353 & 1.285647 & $\mathrm{~T}=5$ \\
\hline
\end{tabular}

Table A2. Growth stage cluster 2

\begin{tabular}{|c|c|c|c|c|c|c|}
\hline Variable & & Mean & Std. dev. & Min & $\operatorname{Max}$ & Observations \\
\hline \multirow[t]{3}{*}{ tobin_q } & overall & 2.337486 & 1.679415 & 0.4497 & 16.643 & $\mathrm{~N}=1415$ \\
\hline & between & & 1.466019 & 0.48728 & 13.66632 & $\mathrm{n}=283$ \\
\hline & within & & 0.822983 & -2.3829 & 7.813385 & $\mathrm{~T}=5$ \\
\hline \multirow[t]{3}{*}{ tsr } & overall & 40.91985 & 502.8293 & -4.21421 & 16511.82 & $\mathrm{~N}=1415$ \\
\hline & between & & 347.8131 & -1.27263 & 5589.596 & $\mathrm{n}=283$ \\
\hline & within & & 363.6008 & -5548.45 & 10963.15 & $\mathrm{~T}=5$ \\
\hline \multirow[t]{3}{*}{ lev } & overall & 0.737901 & 1.866208 & -18.3097 & 48.07089 & $\mathrm{~N}=1415$ \\
\hline & between & & 1.317222 & -0.09889 & 15.12178 & $\mathrm{n}=283$ \\
\hline & within & & 1.323845 & -19.0533 & 33.68701 & $\mathrm{~T}=5$ \\
\hline \multirow[t]{3}{*}{ board } & overall & 8.597173 & 1.985518 & 4 & 16 & $\mathrm{~N}=1415$ \\
\hline & between & & 1.868513 & 4.4 & 14.8 & $\mathrm{n}=283$ \\
\hline & within & & 0.678838 & 3.997173 & 13.99717 & $\mathrm{~T}=5$ \\
\hline
\end{tabular}




\begin{tabular}{|c|c|c|c|c|c|c|}
\hline Variable & & Mean & Std. dev. & Min & $\operatorname{Max}$ & Observations \\
\hline \multirow[t]{3}{*}{ pct_in $\sim t$} & overall & 0.437512 & 0.151705 & 0 & 1 & $\mathrm{~N}=1415$ \\
\hline & between & & 0.13752 & 0 & 0.78546 & $\mathrm{n}=283$ \\
\hline & within & & 0.064469 & 0.037511 & 0.946602 & $\mathrm{~T}=5$ \\
\hline \multirow[t]{3}{*}{ state } & overall & 0.087401 & 0.168064 & 0 & 0.9936 & $\mathrm{~N}=1415$ \\
\hline & between & & 0.167752 & 0 & 0.95932 & $\mathrm{n}=283$ \\
\hline & within & & 0.01357 & -0.24292 & 0.212781 & $\mathrm{~T}=5$ \\
\hline \multirow[t]{3}{*}{ govern $\sim \mathrm{n}$} & overall & 0.015485 & 0.0267 & 0 & 0.15 & $\mathrm{~N}=1415$ \\
\hline & between & & 0.026395 & 0 & 0.15 & $\mathrm{n}=283$ \\
\hline & within & & 0.004264 & -0.01038 & 0.054725 & $\mathrm{~T}=5$ \\
\hline \multirow[t]{3}{*}{ bank_own } & overall & 0.082842 & 0.10061 & -0.01491 & 0.7135 & $\mathrm{~N}=1415$ \\
\hline & between & & 0.094904 & -0.00091 & 0.6059 & $\mathrm{n}=283$ \\
\hline & within & & 0.03378 & -0.24342 & 0.388282 & $\mathrm{~T}=5$ \\
\hline \multirow[t]{3}{*}{ instit $\sim \mathrm{t}$} & overall & 0.158885 & 0.176015 & -0.00626 & 1.0269 & $\mathrm{~N}=1415$ \\
\hline & between & & 0.170241 & 0.000056 & 1.01136 & $\mathrm{n}=283$ \\
\hline & within & & 0.045622 & -0.17202 & 0.389305 & $\mathrm{~T}=5$ \\
\hline \multirow[t]{3}{*}{ insider } & overall & 0.164747 & 0.217287 & -0.13445 & 1.09 & $\mathrm{~N}=1415$ \\
\hline & between & & 0.210303 & -0.00086 & 0.80535 & $\mathrm{n}=283$ \\
\hline & within & & 0.055777 & -0.37455 & 0.553447 & $\mathrm{~T}=5$ \\
\hline \multirow[t]{3}{*}{ concen $\sim \mathrm{n}$} & overall & 0.498703 & 0.258899 & 0 & 0.99 & $\mathrm{~N}=1415$ \\
\hline & between & & 0.259109 & 0 & 0.99 & $\mathrm{n}=283$ \\
\hline & within & & 0.00901 & 0.410703 & 0.762703 & $\mathrm{~T}=5$ \\
\hline \multirow[t]{3}{*}{ roa } & overall & 0.060208 & 0.101889 & -1.48797 & 0.670722 & $\mathrm{~N}=1415$ \\
\hline & between & & 0.08447 & -0.8646 & 0.367768 & $\mathrm{n}=283$ \\
\hline & within & & 0.057153 & -0.56316 & 0.886886 & $\mathrm{~T}=5$ \\
\hline \multirow[t]{3}{*}{ roe } & overall & 0.116599 & 0.211753 & -1.43794 & 1.993605 & $\mathrm{~N}=1415$ \\
\hline & between & & 0.174406 & -1.40432 & 1.323131 & $\mathrm{n}=283$ \\
\hline & within & & 0.12045 & -1.00936 & 1.352754 & $\mathrm{~T}=5$ \\
\hline
\end{tabular}


Table A3. Growth stage cluster 3

\begin{tabular}{|c|c|c|c|c|c|c|}
\hline Variable & & Mean & Std. dev. & Min & Max & Observations \\
\hline \multirow[t]{3}{*}{ tobin_q } & overall & 2.77037 & 2.377286 & 0.5893 & 18 & $\mathrm{~N}=355$ \\
\hline & between & & 1.712549 & 0.88394 & 9.52328 & $\mathrm{n}=71$ \\
\hline & within & & 1.658857 & -1.02871 & 12.94321 & $\mathrm{~T}=5$ \\
\hline \multirow[t]{3}{*}{ tsr } & overall & 11.88545 & 34.52468 & -2.29705 & 286.3989 & $\mathrm{~N}=355$ \\
\hline & between & & 33.75019 & -1.10175 & 262.0519 & $\mathrm{n}=71$ \\
\hline & within & & 8.108586 & -63.5062 & 49.52049 & $\mathrm{~T}=5$ \\
\hline \multirow[t]{3}{*}{ lev } & overall & 0.360834 & 2.281928 & -31.081 & 20.437 & $\mathrm{~N}=355$ \\
\hline & between & & 1.779543 & -12.9207 & 5.970481 & $\mathrm{n}=71$ \\
\hline & within & & 1.440905 & -17.7995 & 14.82735 & $\mathrm{~T}=5$ \\
\hline \multirow[t]{3}{*}{ board } & overall & 8.892958 & 2.386362 & 4 & 15 & $\mathrm{~N}=355$ \\
\hline & between & & 2.270514 & 4.8 & 15 & $\mathrm{n}=71$ \\
\hline & within & & 0.773137 & 5.692958 & 12.09296 & $\mathrm{~T}=5$ \\
\hline \multirow[t]{3}{*}{ pct_in $\sim \mathrm{t}$} & overall & 0.446799 & 0.165829 & 0 & 0.88889 & $\mathrm{~N}=355$ \\
\hline & between & & 0.158728 & 0 & 0.817062 & $\mathrm{n}=71$ \\
\hline & within & & 0.050885 & 0.233459 & 0.700159 & $\mathrm{~T}=5$ \\
\hline \multirow[t]{3}{*}{ state } & overall & 0.159329 & 0.234695 & 0 & 0.9472 & $\mathrm{~N}=355$ \\
\hline & between & & 0.231272 & 0 & 0.9186 & $\mathrm{n}=71$ \\
\hline & within & & 0.046898 & -0.00331 & 0.792189 & $\mathrm{~T}=5$ \\
\hline \multirow[t]{3}{*}{ govern n } & overall & 0.022339 & 0.036414 & 0 & 0.15 & $\mathrm{~N}=355$ \\
\hline & between & & 0.036371 & 0 & 0.15 & $\mathrm{n}=71$ \\
\hline & within & & 0.004249 & 0.004267 & 0.042109 & $\mathrm{~T}=5$ \\
\hline \multirow[t]{3}{*}{ bank_own } & overall & 0.08037 & 0.077964 & -0.00076 & 0.3665 & $\mathrm{~N}=355$ \\
\hline & between & & 0.076345 & 0 & 0.31768 & $\mathrm{n}=71$ \\
\hline & within & & 0.017768 & -0.01959 & 0.14701 & $\mathrm{~T}=5$ \\
\hline \multirow[t]{3}{*}{ instit $\sim t$} & overall & 0.138136 & 0.116368 & -0.00111 & 0.7961 & $\mathrm{~N}=355$ \\
\hline & between & & 0.111543 & 0.00002 & 0.73856 & $\mathrm{n}=71$ \\
\hline & within & & 0.035215 & -0.00828 & 0.332696 & $\mathrm{~T}=5$ \\
\hline
\end{tabular}




\begin{tabular}{|c|c|c|c|c|c|c|}
\hline Variable & & Mean & Std. dev. & Min & $\operatorname{Max}$ & Observations \\
\hline \multirow[t]{3}{*}{ insider } & overall & 0.174883 & 0.207908 & -0.065 & 0.7269 & $\mathrm{~N}=355$ \\
\hline & between & & 0.202094 & 0 & 0.63714 & $\mathrm{n}=71$ \\
\hline & within & & 0.05334 & -0.15172 & 0.588283 & $\mathrm{~T}=5$ \\
\hline \multirow[t]{3}{*}{ concen $\sim \mathrm{n}$} & overall & 0.495916 & 0.267725 & 0 & 0.98 & $\mathrm{~N}=355$ \\
\hline & between & & 0.26923 & 0 & 0.98 & $\mathrm{n}=71$ \\
\hline & within & & 0.003362 & 0.475916 & 0.515916 & $\mathrm{~T}=5$ \\
\hline \multirow[t]{3}{*}{ roa } & overall & 0.060432 & 0.068574 & -0.29829 & 0.348869 & $\mathrm{~N}=355$ \\
\hline & between & & 0.059452 & -0.0863 & 0.291798 & $\mathrm{n}=71$ \\
\hline & within & & 0.034753 & -0.15156 & 0.289008 & $\mathrm{~T}=5$ \\
\hline \multirow[t]{3}{*}{ roe } & overall & 0.108308 & 0.148356 & -1.3984 & 0.779091 & $\mathrm{~N}=355$ \\
\hline & between & & 0.116121 & -0.47178 & 0.384065 & $\mathrm{n}=71$ \\
\hline & within & & 0.093154 & -0.81832 & 0.723212 & $\mathrm{~T}=5$ \\
\hline
\end{tabular}

Table A4. Maturity stage cluster 1

\begin{tabular}{|c|c|c|c|c|c|c|}
\hline Variable & & Mean & Std. dev. & Min & $\operatorname{Max}$ & Observations \\
\hline \multirow[t]{3}{*}{ tobin_q } & overall & 1.965497 & 1.553499 & 0.5441 & 20.3851 & $\mathrm{~N}=1675$ \\
\hline & between & & 1.329455 & 0.61578 & 12.65076 & $\mathrm{n}=335$ \\
\hline & within & & 0.806308 & -6.67266 & 11.60542 & $\mathrm{~T}=5$ \\
\hline \multirow[t]{3}{*}{ tsr } & overall & 56.48936 & 313.3103 & -4.84969 & 5301.354 & $\mathrm{~N}=1675$ \\
\hline & between & & 300.7512 & -1.02385 & 5010.417 & $\mathrm{n}=335$ \\
\hline & within & & 89.04039 & -801.425 & 2821.531 & $\mathrm{~T}=5$ \\
\hline \multirow[t]{3}{*}{ lev } & overall & 0.808137 & 1.832803 & -18.7259 & 43.96485 & $\mathrm{~N}=1675$ \\
\hline & between & & 1.226107 & -3.74636 & 14.68088 & $\mathrm{n}=335$ \\
\hline & within & & 1.363606 & -16.5288 & 30.0921 & $\mathrm{~T}=5$ \\
\hline \multirow[t]{3}{*}{ board } & overall & 9.30806 & 2.262499 & 3 & 20 & $\mathrm{~N}=1675$ \\
\hline & between & & 2.093309 & 3.6 & 18 & $\mathrm{n}=335$ \\
\hline & within & & 0.864541 & 4.30806 & 18.10806 & $\mathrm{~T}=5$ \\
\hline \multirow[t]{2}{*}{ pct_in $\sim \mathrm{t}$} & overall & 0.386705 & 0.125189 & 0 & 1 & $\mathrm{~N}=1675$ \\
\hline & between & & 0.114679 & 0 & 1 & $\mathrm{n}=335$ \\
\hline
\end{tabular}




\begin{tabular}{|c|c|c|c|c|c|c|}
\hline \multirow[t]{2}{*}{ Variable } & & Mean & Std. dev. & Min & $\operatorname{Max}$ & Observations \\
\hline & within & & 0.050521 & 0.044705 & 0.746705 & $\mathrm{~T}=5$ \\
\hline \multirow[t]{3}{*}{ state } & overall & 6.731273 & 12.57613 & 0 & 81.85 & $\mathrm{~N}=1675$ \\
\hline & between & & 12.44834 & 0 & 81.85 & $\mathrm{n}=335$ \\
\hline & within & & 1.888966 & -25.5807 & 33.57127 & $\mathrm{~T}=5$ \\
\hline \multirow[t]{3}{*}{ govern $\sim \mathrm{n}$} & overall & 1.152734 & 2.102637 & 0 & 19 & $\mathrm{~N}=1675$ \\
\hline & between & & 2.053246 & 0 & 19 & $\mathrm{n}=335$ \\
\hline & within & & 0.464044 & -2.28327 & 5.076734 & $\mathrm{~T}=5$ \\
\hline \multirow[t]{3}{*}{ bank_own } & overall & 0.137946 & 0.050262 & 0 & 0.364 & $\mathrm{~N}=1675$ \\
\hline & between & & 0.045771 & 0 & 0.24 & $\mathrm{n}=335$ \\
\hline & within & & 0.020888 & -0.151 & 0.212003 & $\mathrm{~T}=5$ \\
\hline \multirow[t]{3}{*}{ instit $\sim t$} & overall & 0.134708 & 0.177962 & 0 & 1.072 & $\mathrm{~N}=1675$ \\
\hline & between & & 0.168784 & 0 & 1.0162 & $\mathrm{n}=335$ \\
\hline & within & & 0.057014 & -0.27125 & 0.947546 & $\mathrm{~T}=5$ \\
\hline \multirow[t]{3}{*}{ insider } & overall & 0.134708 & 0.150403 & 0 & 2.054 & $\mathrm{~N}=1675$ \\
\hline & between & & 0.132665 & 0 & 0.932 & $\mathrm{n}=335$ \\
\hline & within & & 0.071155 & -0.62629 & 1.256708 & $\mathrm{~T}=5$ \\
\hline \multirow[t]{3}{*}{ concen $\sim \mathrm{n}$} & overall & 0.253152 & 0.157094 & 0.09 & 0.89 & $\mathrm{~N}=1675$ \\
\hline & between & & 0.157278 & 0.09 & 0.89 & $\mathrm{n}=335$ \\
\hline & within & & 0.001093 & 0.233152 & 0.273152 & $\mathrm{~T}=5$ \\
\hline \multirow[t]{3}{*}{ roa } & overall & 4.212624 & 7.470459 & -116.33 & 41.9309 & $\mathrm{~N}=1675$ \\
\hline & between & & 5.531154 & -29.8956 & 25.04652 & $\mathrm{n}=335$ \\
\hline & within & & 5.028637 & -82.2214 & 38.0807 & $\mathrm{~T}=5$ \\
\hline \multirow[t]{3}{*}{ roe } & overall & 6.946358 & 21.2102 & -298.679 & 102.3394 & $N=1675$ \\
\hline & between & & 15.5643 & -107.269 & 45.75316 & $\mathrm{n}=335$ \\
\hline & within & & 14.42927 & -217.236 & 99.26272 & $\mathrm{~T}=5$ \\
\hline
\end{tabular}


Table A5. Maturity stage cluster 2

\begin{tabular}{|c|c|c|c|c|c|c|}
\hline Variable & & Mean & Std. dev. & Min & Max & Observations \\
\hline \multirow[t]{3}{*}{ tobin_q } & overall & 2.072864 & 1.634382 & 0.6384 & 20.3851 & $\mathrm{~N}=1425$ \\
\hline & between & & 1.392216 & 0.71734 & 12.65076 & $\mathrm{n}=285$ \\
\hline & within & & 0.859292 & -6.5653 & 11.71278 & $\mathrm{~T}=5$ \\
\hline \multirow[t]{3}{*}{ tsr } & overall & 58.14478 & 336.3521 & -4.84969 & 5301.354 & $\mathrm{~N}=1425$ \\
\hline & between & & 323.0379 & -1.02385 & 5010.417 & $\mathrm{n}=285$ \\
\hline & within & & 95.24902 & -799.77 & 2823.187 & $\mathrm{~T}=5$ \\
\hline \multirow[t]{3}{*}{ lev } & overall & 0.76561 & 1.727838 & -10.5856 & 43.96485 & $\mathrm{~N}=1425$ \\
\hline & between & & 1.207743 & -1.34786 & 14.68088 & $\mathrm{n}=285$ \\
\hline & within & & 1.237287 & -13.3653 & 30.04958 & $\mathrm{~T}=5$ \\
\hline \multirow[t]{3}{*}{ board } & overall & 9.29684 & 2.190607 & 4 & 20 & $\mathrm{~N}=1425$ \\
\hline & between & & 2.027737 & 5 & 18 & $\mathrm{n}=285$ \\
\hline & within & & 0.83582 & 4.296842 & 18.09684 & $\mathrm{~T}=5$ \\
\hline \multirow[t]{3}{*}{ pct_in $\sim \mathrm{t}$} & overall & 0.39092 & 0.117936 & 0 & 1 & $\mathrm{~N}=1425$ \\
\hline & between & & 0.107529 & 0 & 1 & $\mathrm{n}=285$ \\
\hline & within & & 0.048775 & 0.050006 & 0.750928 & $\mathrm{~T}=5$ \\
\hline \multirow[t]{3}{*}{ state } & overall & 0.07804 & 0.132694 & 0 & 0.8185 & $\mathrm{~N}=1425$ \\
\hline & between & & 0.131612 & 0 & 0.8185 & $\mathrm{n}=285$ \\
\hline & within & & 0.018291 & -0.24508 & 0.346442 & $\mathrm{~T}=5$ \\
\hline \multirow[t]{3}{*}{ govern n } & overall & 0.01171 & 0.021715 & 0 & 0.19 & $\mathrm{~N}=1425$ \\
\hline & between & & 0.021279 & 0 & 0.19 & $\mathrm{n}=285$ \\
\hline & within & & 0.004475 & -0.02265 & 0.050951 & $\mathrm{~T}=5$ \\
\hline \multirow[t]{3}{*}{ bank_own } & overall & 0.03763 & 0.047218 & $1.00 \mathrm{E}-05$ & 0.3639 & $\mathrm{~N}=1425$ \\
\hline & between & & 0.042968 & 0.000018 & 0.2352 & $\mathrm{n}=285$ \\
\hline & within & & 0.01971 & -0.15165 & 0.211001 & $\mathrm{~T}=5$ \\
\hline \multirow[t]{3}{*}{ instit $\sim t$} & overall & 0.08868 & 0.10624 & 0 & 1.0319 & $\mathrm{~N}=1425$ \\
\hline & between & & 0.095225 & 0.000344 & 0.562 & $\mathrm{n}=285$ \\
\hline & within & & 0.047378 & -0.22122 & 0.898281 & $\mathrm{~T}=5$ \\
\hline
\end{tabular}




\begin{tabular}{|c|c|c|c|c|c|c|}
\hline Variable & & Mean & Std. dev. & Min & $\operatorname{Max}$ & Observations \\
\hline \multirow[t]{3}{*}{ insider } & overall & 0.13768 & 0.143092 & 0 & 1.1358 & $\mathrm{~N}=1425$ \\
\hline & between & & 0.126845 & 0 & 0.59158 & $\mathrm{n}=285$ \\
\hline & within & & 0.066563 & -0.26559 & 0.788907 & $\mathrm{~T}=5$ \\
\hline \multirow[t]{3}{*}{ concen $\sim \mathrm{n}$} & overall & 0.22087 & 0.12884 & 0.1045 & 0.47 & $\mathrm{~N}=1425$ \\
\hline & between & & 0.129016 & 0.1045 & 0.47 & $\mathrm{n}=285$ \\
\hline & within & & 0.001185 & 0.200876 & 0.240876 & $\mathrm{~T}=5$ \\
\hline \multirow[t]{3}{*}{ roa } & overall & 4.37339 & 7.381651 & -116.33 & 35.0684 & $\mathrm{~N}=1425$ \\
\hline & between & & 5.408549 & -29.8956 & 24.42556 & $\mathrm{n}=285$ \\
\hline & within & & 5.031753 & -82.0606 & 36.02037 & $\mathrm{~T}=5$ \\
\hline \multirow[t]{3}{*}{ roe } & overall & 7.35076 & 20.13703 & -298.679 & 102.3394 & $\mathrm{~N}=1425$ \\
\hline & between & & 13.63026 & -78.7423 & 45.75316 & $\mathrm{n}=285$ \\
\hline & within & & 14.84041 & -216.831 & 99.66712 & $\mathrm{~T}=5$ \\
\hline
\end{tabular}

Table A6. Maturity stage cluster 3

\begin{tabular}{|c|c|c|c|c|c|c|}
\hline Variable & & Mean & Std. dev. & Min & $\operatorname{Max}$ & Observations \\
\hline \multirow[t]{3}{*}{ tobin_q } & overall & 1.474898 & 0.698037 & 0.4924 & 5.4166 & $\mathrm{~N}=550$ \\
\hline & between & & 0.596287 & 0.72082 & 4.5259 & $\mathrm{n}=110$ \\
\hline & within & & 0.366453 & 0.188038 & 3.481778 & $\mathrm{~T}=5$ \\
\hline \multirow[t]{3}{*}{ tsr } & overall & 50.46057 & 226.7641 & -1.32577 & 4872.531 & $\mathrm{~N}=550$ \\
\hline & between & & 128.1959 & -0.33556 & 1137.164 & $\mathrm{n}=110$ \\
\hline & within & & 187.37 & -1086.51 & 3785.828 & $\mathrm{~T}=5$ \\
\hline \multirow[t]{3}{*}{ lev } & overall & 1.166086 & 1.492747 & 0 & 18.21384 & $\mathrm{~N}=550$ \\
\hline & between & & 1.2684 & 0 & 8.4674 & $\mathrm{n}=110$ \\
\hline & within & & 0.794467 & -4.67595 & 10.91253 & $\mathrm{~T}=5$ \\
\hline \multirow[t]{3}{*}{ board } & overall & 9.649091 & 2.131076 & 5 & 20 & $\mathrm{~N}=550$ \\
\hline & between & & 1.970086 & 5.2 & 18.6 & $\mathrm{n}=110$ \\
\hline & within & & 0.829774 & 5.049091 & 14.44909 & $\mathrm{~T}=5$ \\
\hline \multirow[t]{2}{*}{ pct_in t } & overall & 0.408721 & 0.097603 & 0 & 0.8 & $\mathrm{~N}=550$ \\
\hline & between & & 0.085469 & 0.27857 & 0.70477 & $\mathrm{n}=110$ \\
\hline
\end{tabular}




\begin{tabular}{|c|c|c|c|c|c|c|}
\hline \multirow[t]{2}{*}{ Variable } & & Mean & Std. dev. & Min & $\operatorname{Max}$ & Observations \\
\hline & within & & 0.047694 & 0.094437 & 0.665857 & $\mathrm{~T}=5$ \\
\hline \multirow[t]{3}{*}{ state } & overall & 0.055514 & 0.084268 & 0 & 0.3332 & $\mathrm{~N}=550$ \\
\hline & between & & 0.084254 & 0 & 0.33 & $\mathrm{n}=110$ \\
\hline & within & & 0.007361 & -0.00469 & 0.152714 & $\mathrm{~T}=5$ \\
\hline \multirow[t]{3}{*}{ govern $\sim \mathrm{n}$} & overall & 0.008709 & 0.019562 & 0 & 0.15 & $\mathrm{~N}=550$ \\
\hline & between & & 0.018908 & 0 & 0.15 & $\mathrm{n}=110$ \\
\hline & within & & 0.005269 & -0.01715 & 0.047949 & $\mathrm{~T}=5$ \\
\hline \multirow[t]{3}{*}{ bank_own } & overall & 0.045463 & 0.052978 & $1.00 \mathrm{E}-05$ & 0.3639 & $\mathrm{~N}=550$ \\
\hline & between & & 0.045781 & 0.000018 & 0.2033 & $\mathrm{n}=110$ \\
\hline & within & & 0.026945 & -0.14382 & 0.306845 & $\mathrm{~T}=5$ \\
\hline \multirow[t]{3}{*}{ instit t } & overall & 0.0741 & 0.087186 & 1.00 & 0.3871 & $\mathrm{~N}=550$ \\
\hline & between & & 0.075385 & 0.004004 & 0.3333 & $\mathrm{n}=110$ \\
\hline & within & & 0.044272 & -0.07198 & 0.27922 & $\mathrm{~T}=5$ \\
\hline \multirow[t]{3}{*}{ insider } & overall & 0.423428 & 0.210628 & 0 & 1.0537 & $\mathrm{~N}=550$ \\
\hline & between & & 0.185147 & 0.0581 & 0.78596 & $\mathrm{n}=110$ \\
\hline & within & & 0.101658 & -0.02127 & 1.016548 & $\mathrm{~T}=5$ \\
\hline \multirow[t]{3}{*}{ concen $\sim \mathrm{n}$} & overall & 0.339262 & 0.133421 & 0.1045 & 0.4298 & $\mathrm{~N}=550$ \\
\hline & between & & 0.133903 & 0.1045 & 0.4298 & $\mathrm{n}=110$ \\
\hline & within & & 0.00135 & 0.319262 & 0.359262 & $\mathrm{~T}=5$ \\
\hline \multirow[t]{3}{*}{ roa } & overall & 2.9193 & 5.408142 & -35.1906 & 26.526 & $\mathrm{~N}=550$ \\
\hline & between & & 4.31178 & -11.9749 & 22.6251 & $\mathrm{n}=110$ \\
\hline & within & & 3.285119 & -20.2963 & 17.9391 & $\mathrm{~T}=5$ \\
\hline \multirow[t]{3}{*}{ roe } & overall & 4.81813 & 20.2548 & -157.696 & 55.775 & $\mathrm{~N}=550$ \\
\hline & between & & 16.53957 & -121.588 & 40.0548 & $\mathrm{n}=110$ \\
\hline & within & & 11.7768 & -99.4144 & 118.224 & $\mathrm{~T}=5$ \\
\hline
\end{tabular}


Table A7. Decline stage cluster 1

\begin{tabular}{|c|c|c|c|c|c|c|}
\hline Variable & & Mean & Std. dev. & Min & $\operatorname{Max}$ & Observations \\
\hline \multirow[t]{3}{*}{ tobin_q } & overall & 3.035023 & 7.683356 & 0.3442 & 90.3223 & $\mathrm{~N}=865$ \\
\hline & between & & 7.33779 & 0.5179 & 89.5223 & $n=173$ \\
\hline & within & & 2.332398 & -18.9177 & 49.62074 & $\mathrm{~T}=5$ \\
\hline \multirow[t]{3}{*}{ tsr } & overall & 38.96511 & 149.5061 & -4.2609 & 1792.88 & $N=865$ \\
\hline & between & & 131.9693 & -2.8609 & 833.7818 & $\mathrm{n}=173$ \\
\hline & within & & 70.82952 & -614.54 & 1177.911 & $\mathrm{~T}=5$ \\
\hline \multirow[t]{3}{*}{ lev } & overall & 0.094357 & 0.243607 & -3.16353 & 2.492012 & $N=865$ \\
\hline & between & & 0.174699 & -0.44067 & 1.566804 & $\mathrm{n}=173$ \\
\hline & within & & 0.170193 & -2.6285 & 1.237634 & $\mathrm{~T}=5$ \\
\hline \multirow[t]{3}{*}{ board } & overall & 9.195376 & 2.718247 & 4 & 19 & $N=865$ \\
\hline & between & & 2.640996 & 5 & 18.8 & $\mathrm{n}=173$ \\
\hline & within & & 0.668054 & 4.795376 & 13.99538 & $\mathrm{~T}=5$ \\
\hline \multirow[t]{3}{*}{ pct_in $\sim t$} & overall & 0.382275 & 0.134349 & 0 & 0.85714 & $\mathrm{~N}=865$ \\
\hline & between & & 0.129653 & 0.12456 & 0.82381 & $\mathrm{n}=173$ \\
\hline & within & & 0.036296 & 0.162275 & 0.862275 & $\mathrm{~T}=5$ \\
\hline \multirow[t]{3}{*}{ state } & overall & 0.095618 & 0.118535 & 0 & 0.5765 & $N=865$ \\
\hline & between & & 0.117896 & 0 & 0.5765 & $n=173$ \\
\hline & within & & 0.014678 & 0.021618 & 0.391618 & $\mathrm{~T}=5$ \\
\hline \multirow[t]{3}{*}{ govern $\sim \mathrm{n}$} & overall & 0.0062 & 0.015732 & 0 & 0.1541 & $\mathrm{~N}=865$ \\
\hline & between & & 0.015513 & 0 & 0.15152 & $\mathrm{n}=173$ \\
\hline & within & & 0.002819 & -0.007 & 0.02606 & $\mathrm{~T}=5$ \\
\hline \multirow[t]{3}{*}{ bank_own } & overall & 0.13496 & 0.085423 & 0 & 0.5297 & $\mathrm{~N}=865$ \\
\hline & between & & 0.078616 & 0 & 0.43394 & $n=173$ \\
\hline & within & & 0.033841 & -0.04912 & 0.31288 & $\mathrm{~T}=5$ \\
\hline \multirow[t]{3}{*}{ instit $\sim \mathrm{t}$} & overall & 0.155016 & 0.140042 & 0 & 0.8653 & $\mathrm{~N}=865$ \\
\hline & between & & 0.131461 & 0.00041 & 0.71732 & $\mathrm{n}=173$ \\
\hline & within & & 0.049089 & -0.27222 & 0.411876 & $\mathrm{~T}=5$ \\
\hline
\end{tabular}




\begin{tabular}{|c|c|c|c|c|c|c|}
\hline Variable & & Mean & Std. dev. & Min & $\operatorname{Max}$ & Observations \\
\hline \multirow[t]{3}{*}{ insider } & overall & 0.25979 & 0.246968 & 0 & 1.0011 & $\mathrm{~N}=865$ \\
\hline & between & & 0.232007 & 0 & 0.9761 & $\mathrm{n}=173$ \\
\hline & within & & 0.086111 & -0.25021 & 0.942932 & $\mathrm{~T}=5$ \\
\hline \multirow[t]{3}{*}{ concen $\sim \mathrm{n}$} & overall & 0.2975 & 0.14045 & 0.1798 & 0.87 & $\mathrm{~N}=865$ \\
\hline & between & & 0.140615 & 0.1798 & 0.87 & $\mathrm{n}=173$ \\
\hline & within & & 0.006729 & 0.25357 & 0.47357 & $\mathrm{~T}=5$ \\
\hline \multirow[t]{3}{*}{ roa } & overall & 3.7095 & 13.81502 & -198.669 & 75.1724 & $\mathrm{~N}=865$ \\
\hline & between & & 11.06937 & -94.3916 & 27.86318 & $\mathrm{n}=173$ \\
\hline & within & & 8.300058 & -100.568 & 70.67546 & $\mathrm{~T}=5$ \\
\hline \multirow[t]{3}{*}{ roe } & overall & & 23.47372 & -156.511 & 185.5346 & $\mathrm{~N}=865$ \\
\hline & between & 8.51947 & 17.78436 & -107.115 & 78.48008 & $\mathrm{n}=173$ \\
\hline & within & & 15.36869 & -113.443 & 121.6302 & $\mathrm{~T}=5$ \\
\hline
\end{tabular}

